\title{
The Petrology and Mineralogy of the Kimberlite Blow in Letšeng- la-Terae: Implication for its Parental Magma Composition
}

\author{
Natalia Stamm and Max W. Schmidt \\ ETH Zurich, Institute of Geochemistry and Petrology, Zurich, Switzerland,natalia.stamm@erdw.ethz.ch, \\ max.schmidt@erdw.ethz.ch
}

\section{Introduction}

Letšeng-la-Terae, situated in the Maluti Mountains of Lesotho, Southern Africa, is famous for its large high-value, top quality diamonds hosted in two rather low-grade kimberlite bodies (Bowen et al. 2009). Several diatreme facies can be distinguished in the Main and Satellite pipes but fluids alterated and overprinted most of the deposits, obfuscating the characteristics of the parent magma. In the vicinity of the two pipes, a kimberlite blow intruded the flood basalts of the Drakensberg. Also the kimberlite blow exhibits various degrees of alteration, captured in different stages of olivine degradation. Nevertheless, an unusual fresh macrocryst-rich sample could be recovered with only slightly serpentinized olivine, fresh groundmass monticellite and symplectitic intergrowth of calcite and apatite, indicating very little syn- and post-emplacement modifications. For this sample we studied mineral, groundmass and bulk compositions with the aim to identify the parent kimberlite melt of Letšeng.

\section{The Xenolithic Suite of the Kimberlite Blow}

Mineral compositions of macrocryst and groundmass phases were measured by electron microprobe and LA-ICP-MS. In combination with textural observations, we were able to discriminate between xenolithic and primary phases.

Anhedral, rounded olivine macrocrysts $(>1 \mathrm{~mm})$ have homogenous either relatively Fe-rich $\left(\mathrm{Fo}_{<83}\right)$ or Mg-rich $\left(\mathrm{Fo}_{>89}\right)$ cores. Regardless of their core compositions, they all exhibit thin $(<50 \mu \mathrm{m})$ overgrowth rims of $\mathrm{Fo}_{\sim 87}$. This compositionally homogenous overgrowth indicates that the cores of these olivine macrocrysts were in disequilibrium with the host melt. They were hence picked up during ascent, Fe-rich cores fits with the megacryst suite supposed to be formed at the base of the

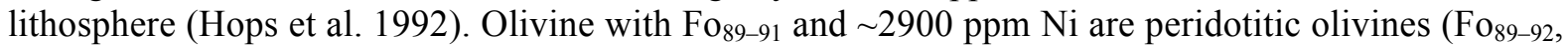
2800-3100 ppm Ni, Herzberg et al. 2013) and Mg-rich olivines with Fo $>92$ represent depleted (harzburgitic/dunitic) mantle (Bernstein et al. 2007). After entrainment, the overgrowth rims crystallized from the kimberlite magma.

Resorbed orthopyroxene macrocrysts are less common than olivine. They are bronzitic in composition $(\mathrm{Mg} \#$ of 87.5$)$ and are akin to the megacryst suite, together with the Fe-rich olivines. Orthopyroxene cores are rimmed by a reaction corona, which consists of olivine, serpentine, K-richterite, diopside and mica. Assuming that this reaction corona was formed by the disequilibrium between the kimberlite melt and the entrained orthopyroxene, the melt would need to be fairly alkaline to form Krichterite containing $4.1-4.6 \mathrm{wt} \% \mathrm{Na}_{2} \mathrm{O}$ and $3.9-4.3 \mathrm{wt} \% \mathrm{~K}_{2} \mathrm{O}$.

\section{The Groundmass Assemblage of the Kimberlite Blow}

Subhedral to euhedral olivine microcrysts $(<0.5 \mathrm{~mm})$ are homogeneous in composition $\left(\mathrm{Fo}_{86-88}\right)$. They are primary, crystallized from the kimberlite melt and constitute by far the largest groundmass phase, which has otherwise mineral sizes $<100 \mu \mathrm{m}$. Olivine crystallization is followed by spinel with initially Cr-rich composition, changing to magnesio-ulvöspinel and finally magnetite. These three stages are manifested in overgrowth of the earlier spinel generation(s) but also by additional nucleation (Fig. 1). Perovskite crystallized together with magnesio-ulvöspinel. Trace element compositions measured in perovskite indicate that this mineral is the main host of rare earth and HFS elements. Groundmass 
perovskite and spinel were also used for high-precision U-Pb dating. Perovskite was dated using IDTIMS, spinel used for initial $\mathrm{Pb}$ correction, yielding an emplacement age of the kimberlite blow of $85.5 \pm 0.3(2 \sigma)$ Ma. Fresh monticellite, Sr-rich carbonate and phlogopite subsequently crystallized from the kimberlite magma, followed by apatite and calcite (Fig. 1). The mineral compositions and observed crystallization sequence suggest that the groundmass phases are primary and best represent the kimberlite melt at near-surface conditions.
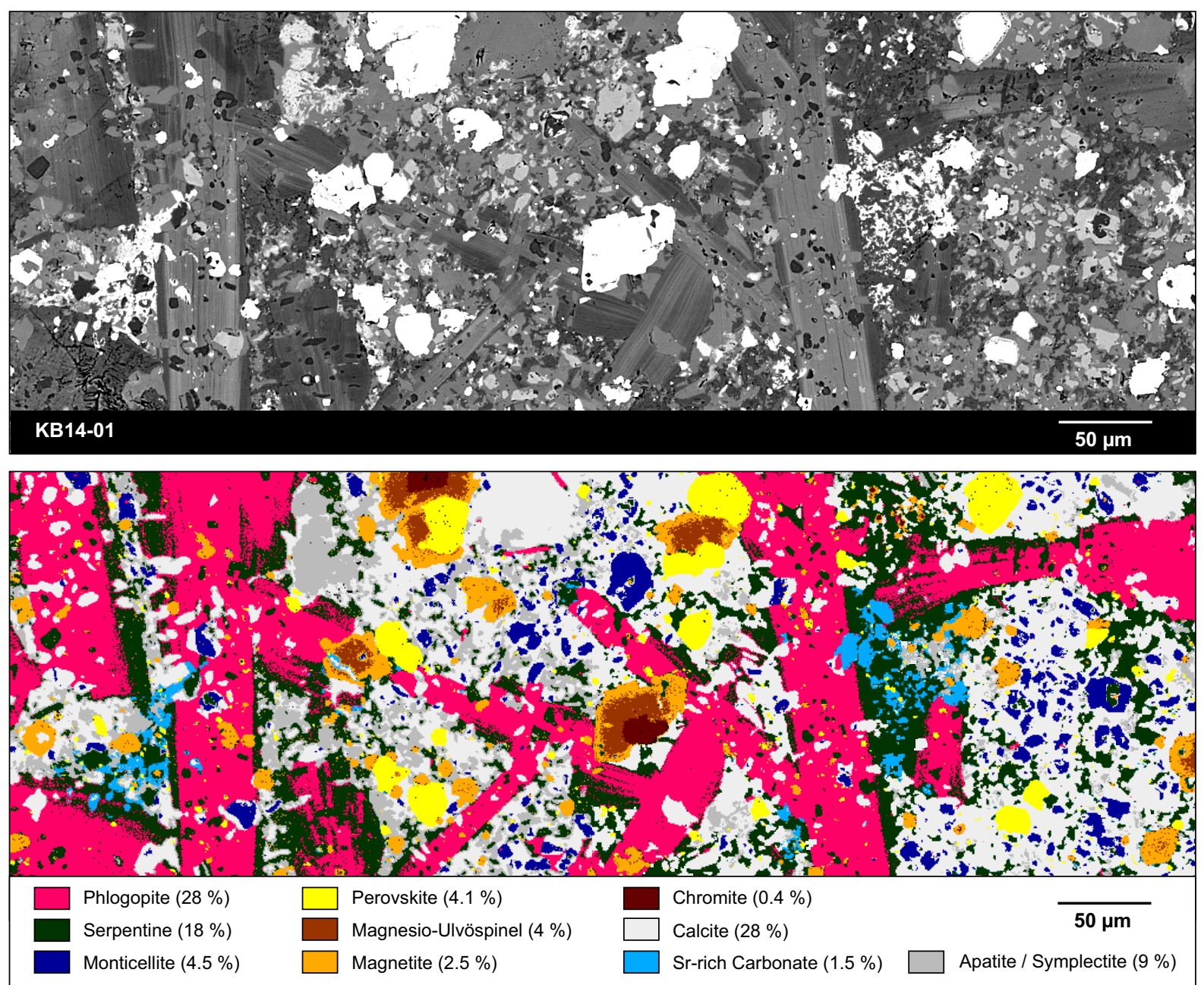

Figure 1: Groundmass characteristics of the kimberlite blow. BSE image showing representative section of the groundmass with corresponding phase map created using the iSpectra toolbox (Liebske 2015). Percentages in the legend indicate the phase abundance present in this particular section. Olivine with grain sizes $>0.1 \mathrm{~mm}$ is not shown.

\section{Bulk Rock Composition of the Kimberlite Blow}

Because the kimberlite blow contains 20-36 vol\% xenolithic olivine, orthopyroxene and minor microxenoliths, whole-rock geochemistry does not correspond to the parent magma composition. Nevertheless, to assess heterogeneity, three whole-rock analyses were performed and compared to the groundmass composition. Groundmass was extracted from six thick sections by micro-drilling and analyzed for its bulk composition.

The groundmass bulk has $24-26 \mathrm{wt} \% \mathrm{SiO}_{2}, 3.3 \mathrm{wt} \% \mathrm{TiO}_{2}, 2.7-2.9 \mathrm{wt} \% \mathrm{Al}_{2} \mathrm{O}_{3}, 10-11 \mathrm{wt} \% \mathrm{FeO}_{\text {tot }}$, 660-1010 ppm Cr, 400-550 ppm Ni, 0.2 wt\% MnO, 20-21 wt\% MgO, 16-19 wt\% CaO, $0.1 \mathrm{wt} \%$ $\mathrm{Na}_{2} \mathrm{O}$, 1.9-2.1 $\mathrm{wt} \% \mathrm{~K}_{2} \mathrm{O}$ and $1.0-1.3 \mathrm{wt} \% \mathrm{P}_{2} \mathrm{O}_{5}$. Resulting $\mathrm{Mg} \#$ of $77.9 \pm 0.2(1 \sigma)$ and $\mathrm{MgO} / \mathrm{CaO}$ of $1.1-1.4$ are lower than the whole-rock $(\mathrm{Mg} \#$ of $79.9 \pm 1.3(1 \sigma)$ and $\mathrm{MgO} / \mathrm{CaO}$ of $1.7 \pm 0.2(1 \sigma)$ ), which approximates the close-to-primary composition proposed for Group-I kimberlites from South 
Africa (Mg\# of 84 and $\mathrm{MgO} / \mathrm{CaO}$ of 1.9, Becker and Le Roex 2006). The low Mg\# in combination with low $\mathrm{Ni}$ might suggest olivine fractionation along the ascent. However, much higher $\mathrm{Ni}$ concentrations are unrealistic in the Letšeng melt and the low $\mathrm{Mg}$ and $\mathrm{Ni}$ are probably parental. Primitive-mantle normalized trace element patterns (Fig. 2) overlap with proposed close-to-primary Group-I kimberlites (Becker and Le Roex, 2006), except for higher Rb, Ba, K and especially Sr. Isotopic compositions of the kimberlite blow with ${ }^{87} \mathrm{Sr}^{86} \mathrm{Sr}_{(\mathrm{i})}$ of $0.703602-0.703656,{ }^{144} \mathrm{Nd} /{ }^{143} \mathrm{Nd}_{(\mathrm{i})}$ of 0.512660 and ${ }^{176} \mathrm{Hf} /{ }^{177} \mathrm{Hf}_{(\mathrm{i})}$ of $0.282671-0.282749$ clearly classify Letšeng as Group-I kimberlite; the elevated concentrations of LILE are likely a primary characteristic of Letšeng.

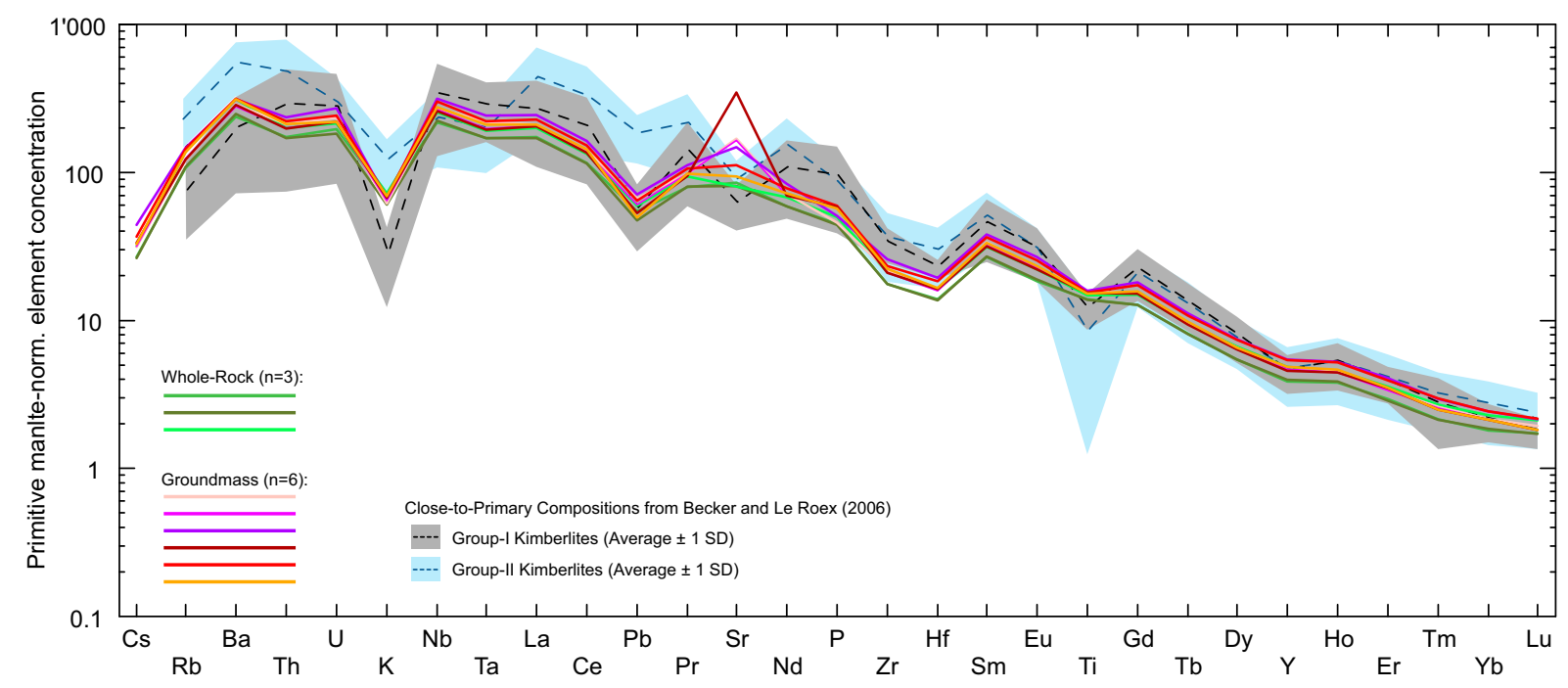

Figure 2: Trace element compositions of the kimberlite blow shown as primitive mantle-normalized element concentrations (normalized after Sun and McDonough, 1989). The three whole-rock and six groundmass analyses are compared with close to primary compositions from Becker and Le Roex, 2006.

The characteristic mineral assemblage with equilibrium olivine microcrysts and the observed major and trace element concentrations complement each other such that the groundmass composition of the kimberlite blow can be regarded as plausible parental melt of the Letšeng kimberlite. However, degassing certainly occurred along the ascent, reducing volatiles and possibly removing some alkalis.

Acknowledgment: We want to express our cordial thanks to Letšeng Diamonds (Pty.) Ltd. for permitting access to the mining area and the possibility of rock sampling.

\section{References}

Becker M, Le Roex AP (2006) Geochemistry of South African On- and Off-craton, Group I and Group II kimberlites: Petrogenesis and Source Region Evolution. J Petrol 47(4):673-703

Bernstein S, Kelemen PB, Hanghoj K (2007) Consistent olivine Mg\# in cratonic mantle reflects Archean mantle melting to the exhaustion of orthopyroxene. Geology 35(5):459-462

Bowen DC, Ferraris RD, Palmer CE, Ward JD (2009) On the unusual characteristics of the diamonds from Letšeng-la-Terae kimberlites, Lesotho. Lithos 112:767-774

Herzberg C, Asimow PD, Ionov DA, Vidito C, Jackson MG, Geist D (2013) Nickel and helium evidence for melt above the core-mantle boundary. Nature 493(7432):393-398

Hops JJ, Gurney JJ, Harte B (1992) The Jagersfontein Cr-poor megacryst suite - towards a model for megacryst petrogenesis. J Volcanol Geoth Res 50(1-2):143-160

Liebske C (2015) iSpectra: An Open Source Toolbox For The Analysis of Spectral Images Recorded on Scanning Electron Microscopes. Microsc Microanal 21(4):1006-1016

Sun SS, McDonough WF (1989) Chemical and isotopic systematics of oceanic basalts: Implications for mantle composition and processes. Geological Society, London, Special Publications 42:313345 